\title{
Falx Cerebelli
}

National Cancer Institute

\section{Source}

National Cancer Institute. Falx Cerebelli. NCI Thesaurus. Code C32584.

A small triangular process of dura matter beginning at the internal occipital crest just beneath the tentorium and projecting forward. 